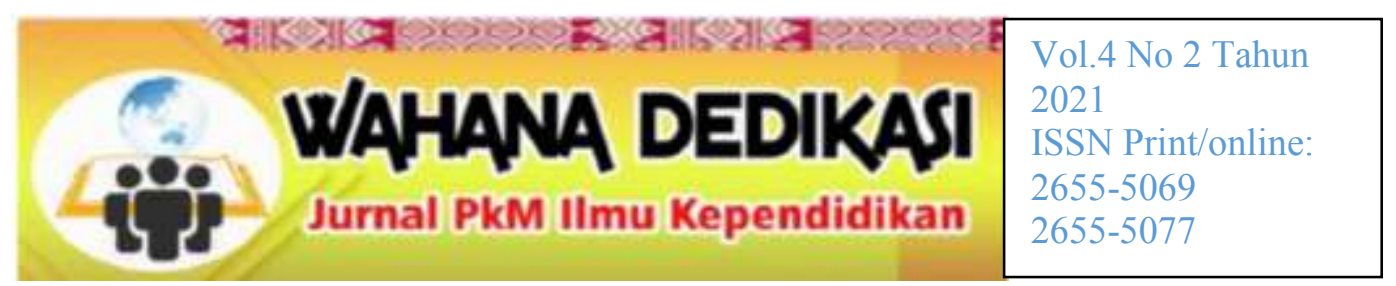

\title{
PENCEGAHAN RISIKO PANDEMI COVID-19 MELALUI PENDIDIKAN MITIGASI BENCANA PADA MASYARAKAT
}

\author{
Ika Meviana ${ }^{1}$, Dwi Kurniawati ${ }^{2}$, Anggi Meilani ${ }^{3}$ \\ Program Studi Pendidikan GeografiUniversitasPGRI Kanjuruhan Malang ${ }^{1,2,3}$ \\ meviana@unikama.ac.id ${ }^{1}, \underline{\text { dwikur@unikama.ac.id }}$, meilania837@gmail.com ${ }^{3}$
}

\begin{abstract}
Abstrak
Kecamatan Dau merupakan kecamatan pertama ditemukan kasus positif covid-19 dimana langsung dinyatakan meninggal. Dengan adanya kasus ini maka semua pihak dikerahkan untuk menerapkan sistem siaga menghadapi bencana dengan mengikutkan berbagai pihak. Program Abdimas ini ditekankan pada kegiatan sosialisasi dan pelatihan manajemen mitigasi bencana nonalam yaitu pandemi Covid-19. Berdasarkan masalah tersebut, metode pendekatan untuk pemecahan masalah menggunakan pelatihan dan pendampingan kepada masyarakat di Kecamatan Dau kususnya Desa Kucur. Sebagai bahan sosialisasi disusun materi berdasarkan hasil analisis kebutuhan peserta dengan melibatkan masyarakat dalam pelaksanaan sosialisasi. Hal tersebut dilakukan guna mengetahui kondisi dan kebutuhan peserta sosialisasi sehingga materi pelatihan dapat sesuai kebutuhan dan dapat berjalan secara efektif dan efisien. Hasil evalusi tentang pemahaman masyarakat berdasarkan hasil angket Pencegahan Risiko Pandemi Covid-19 melalui Pendidikan Mitigasi Bencana yang diisi oleh responden dilihat dari aspek pengetahuan, sikap, dan tindakan dikategorikan memiliki tingkat pemahaman yang sedang. Berdasarkan hasil pengabdian disarankan bahwa perilaku masyarakat dalam menjaga hidup bersih dan sehat serta sikap patuh dalam menerapkan protokol kesehatan di masa pandemi Covid-19 perlu ditingkatkan.
\end{abstract}

Kata kunci:Risiko, Covid-19, Mitigasi Bencana

\begin{abstract}
Dau Sub-district was the first sub-district to find a positive case of Covid-19 which was immediately declared dead. With this case, all parties are mobilized to implement a disaster preparedness system by involving various parties. The Abdimas program emphasizes socialization activities and non-natural disaster management training, namely the Covid-19 pandemic. Based on these problems, the approach method for problem solving uses training and assistance to the community in Dau District, especially Kucur Village. As a material for socialization, materials are prepared based on the results of the analysis of the needs of participants by involving the community in the implementation of socialization. This is done to find out the conditions and needs of the participants so that the training materials can be as needed and can run effectively and efficiently. The results of the evaluation of public understanding based on the
\end{abstract}




\title{
WAHANA DEDIKASI
}

results of the Covid-19 Pandemic Risk Prevention questionnaire through Disaster Mitigation Education which were filled out by respondents in terms of knowledge, attitudes, and actions were categorized as having a moderate level of understanding. Based on the results of the service, it is suggested that people's behavior in maintaining a clean and healthy life and obedient attitude in implementing health protocols during the Covid-19 pandemic needs to be improved.

\section{Keywords:Risk, Covid-19, Disaster Mitigation}

\author{
Artikel disetujui tanggal: 03 September 2021 \\ Corresponden Author:Ika Meviana e-mail:meviana@unikama.ac.id \\ DOI: http://dx.doi.org/10.31851/dedikasi.v4i2.6351 d
}

\section{PENDAHULUAN}

Kabupaten Malang juga tidak lepas dari adanya kasus positif Covid19 dimana data yang tertulis terbagi menjadi kota Malang dengan 53 kasus, kabupaten Malang 90 kasus, dan kota Batu 35 kasus (Surya Malang.com). Berdasarkan data seMalang Raya dapat dilihat bahwa kabupaten Malang memiliki kasus positif covid-19 terbanyak. Kasus positif Corona pertama di kota Malang terjadi pada pertengahan bulan Maret yakni seorang mahasiswa salah satu universitas di Malang dan satu orang lagi yang dinyatakan telah meninggal. Sedangkan empat orang dinyatakan ODP (Orang Dalam Pengawasan) dikarenakan telah bepergian dari luar kota. Denganadanyawabahtersebuttentunya sangatberdampakbagimasyarakat.

Dampak yang dapat dirasakan saatini seperti, ekonomi, kesehatan, sosial, budaya, dan bahkan pendidikan(Imansyah, 2021).

Kecamatan Dau merupakan kecamatan pertama ditemukan kasus positif covid-19dimana langsung dinyatakan meninggal. Dengan adanya kasus ini maka semua pihak dikerahkan untuk menerapkan sistem siaga menghadapi bencana dengan mengikutkan berbagai pihak. Ketua Satgas Penanganan dan Pencegahan Covid 19 di Kabupaten Malang mengatakan dalam mengatasi pandemi ini dilakukan dengan langkah-langkah sebagaimana dalam menghadapi bencana yang harus dilakukan secara bersama-sama dengan mengerahkanpetugas kesehatan. Namun tidak hanya petugas kesehatan saja yang harus bertanggung jawab tetapi semua pihak(Setiawan, 2020).

Selain dipengaruhi oleh daya tahan tubuh, faktor informasi juga dapat mempengaruhi masyarakat dalam upaya pencegahan Covid-19. Kurangnya sosialisasi dan edukasi kepada masyarakat dapat menjadi faktor penting agar masyarakat benarbenar dapat memahami dan melakukan pencegahan penyebaran Covid-19. Terutama pada masyarakat di kecamatan Dau yang tidak semuanya memiliki pemahaman dan kemampuan dalam pencegahan Covid-19.

Tujuan dari kegiatan ini adalah melakukan pencegahan risiko pandemi Covid-19 melalui pendidikan mitigasi bencana pada masyarakat Kecamatan Dau Kabupaten Malang. Diharapkan pasca 


\section{WAHANA DEDIKASI}

mengikuti kegiatan sosialisasi ini, pengetahuan masyarakat tentang mitigasi bencana pencegahan risiko pandemi Covid-19 dapat meningkat.

\section{Permasalahan Mitra}

Permasalahan yang dihadapi mitra setelah pengabdi melakukan analisis situasi sebagai berikut:

1. Kurangnya informasi penyebaran kasus covid-19.

2. Kurangnya pengetahuan, pemahaman dan kesadaran masyarakat dalam memitigasi bencana pandemi covid-19, khususnya pada masyarakat lansia dan anak-anak.

3. Kasus positif covid-19 didominasi oleh lansia.

\section{BAHAN DAN METODE}

Rendahnya

kepedulian masyarakat untuk meminimalkan penyebaran wabah covid-19 dikarenakan masih kurangnya pemahaman terhadap wabah covid-19 yang sudah menjadi pandemi ini. Pengabdi melakukan sosialisasi dan pendampingan kepada masyarakat sebagai metode yang dipilih untukmengatasipermasalahantersebut. Kegiatanpengabdianinidilaksanakan pada tanggal 28 Mei s.d 3 Juni 2021. Objek kegiatan pengabdian ini adalah masyarakat Desa Kucur.

Kerangka pemecahan masalah dan metode yang digunakan dijabarkan pada tabel 1 .

Tabel 1. Kerangka Pemecahan Masalah

\begin{tabular}{cccc}
\hline N & Permasal & Metode & Solusi \\
Pendekat & yang \\
Ditawarka \\
ahan & an & n \\
\hline
\end{tabular}

\begin{tabular}{|c|c|c|c|}
\hline 1 & $\begin{array}{l}\text { Kurangny } \\
\text { a } \\
\text { informasi } \\
\text { penyebara } \\
\text { n kasus } \\
\text { covid-19 }\end{array}$ & $\begin{array}{l}\text { Sosialisas } \\
\text { i dan } \\
\text { pendampi } \\
\text { ngan }\end{array}$ & $\begin{array}{l}\text { 1. Menyed } \\
\text { iakan } \\
\text { peta } \\
\text { penyeba } \\
\text { ran } \\
\text { covid- } \\
19 \\
\text { 2. Sosialis } \\
\text { asi peta } \\
\text { penyeba } \\
\text { ran } \\
\text { kasus } \\
\text { covid- } \\
19\end{array}$ \\
\hline 2 & $\begin{array}{l}\text { Kurangny } \\
\text { a } \\
\text { pengetahu } \\
\text { an, } \\
\text { pemaham } \\
\text { an dan } \\
\text { kesadaran } \\
\text { masyarak } \\
\text { at dalam } \\
\text { memitigas } \\
\text { i bencana } \\
\text { pandemi } \\
\text { covid-19, } \\
\text { khususny } \\
\text { a pada } \\
\text { masyarak } \\
\text { at lansia } \\
\text { dan anak- } \\
\text { anak }\end{array}$ & $\begin{array}{l}\text { Sosialisas } \\
\text { i dan } \\
\text { pendampi } \\
\text { ngan }\end{array}$ & $\begin{array}{l}\text { Sosialisasi } \\
\text { dan } \\
\text { pendampin } \\
\text { gan tentang } \\
\text { mitigasi } \\
\text { bencana } \\
\text { pandemi } \\
\text { covid-19 di } \\
\text { wilayah } \\
\text { pengabdian }\end{array}$ \\
\hline 3 & $\begin{array}{l}\text { Kasus } \\
\text { positif } \\
\text { covid-19 } \\
\text { didominas } \\
\text { i oleh } \\
\text { lansia. }\end{array}$ & $\begin{array}{l}\text { Sosialisas } \\
\text { i dan } \\
\text { pendampi } \\
\text { ngan }\end{array}$ & $\begin{array}{l}\text { Sosialisasi } \\
\text { dan } \\
\text { pendampin } \\
\text { gan tentang } \\
\text { mitigasi } \\
\text { bencana } \\
\text { pandemi } \\
\text { covid-19 di } \\
\text { wilayah } \\
\text { pengabdian }\end{array}$ \\
\hline
\end{tabular}




\section{WAHANA DEDIKASI}

HASIL DAN PEMBAHASAN

\section{Hasil}

Berdasarkan kegiatan pengabdian masyarakat di Desa Kucur Kecamatan Dau yang sudah dilaksanakan, diperoleh hasil sebagai berikut:

1. Materi dapat disampaikan dengan baik kepada masyarakat meskipun ada beberapa yang belum bisa maksimal. Materi disampaikan dengan membagikan pamflet mitigasi bencana pencegahan risiko Covid-19 yang berisi; 1) peta persebaran Covid-19; 2) pengertian Covid-19; 3) strategi mitigasi penularan Covid-19; 4) dan langkah pencegahan penularan Covid-19. Pengabdi dan masyarakat melakukan diskusi tentang informasi seputar covid19. Kemudian diakhir diskusi, pengabdi memberikan angket pencegahan risiko pandemi covid19.

2. Masyarakat memberikan respon positif meskipun masih ada beberapa yang kurang berkenan dengan adanya kegiatan tersebut. Respon positif masyarakat ditunjukkan dengan antusias masyarakat dalam menerima pengabdi dan diskusi bersama. Masyarakat juga menyampaikan informasi yang diperoleh dari pengalaman pribadi maupun orang lain saat diskusi.

3. Peserta sosialisasi cukup memahami materi yang disampaikan oleh pengabdi tentang mitigasi bencana pencegahan risiko Covid-19.

4. Pemahaman berdasarkan $\begin{array}{rr}\text { masyarakat } \\ \text { hasil } & \text { angket } \\ \text { Risiko } & \text { Pandemi }\end{array}$
Covid-19 melalui Pendidikan Mitigasi Bencana yang diisi oleh responden dilihat dari aspek pengetahuan, sikap, dan tindakan dikategorikan memiliki tingkat pemahaman yang sedang.

\section{Pembahasan}

Pemahaman tentang Pencegahan Risiko Pandemi Covid19 melalui Pendidikan Mitigasi Bencana bagi masyarakat Kecamatan Dau kususnya Desa Kucur perlu diberikan. (Abdullah, 2018), menjelaskan bahwa mitigasi atau upaya mengurangi risiko bencana perlu dan sangat penting untuk dipahami oleh masyarakat. Hal tersebut bermanfaat agar masyarakat lebih trampil, cekatan dan terlatih dalam menolong dirinya sendiri saat terjadi bencana. Hal ini dikarenakan Kecamatan Dau merupakan kecamatan pertama ditemukan kasus positif covid-19 di Kabupaten Malang dimana langsung dinyatakan meninggal. Berdasarkan kegiatan pengabdian yang dilakukan diperoleh hasil bahwa sebagian besar pemahaman masyarakat Kecamatan Dau khususnya Desa Kucur memiliki tingkat pemahaman sedang. Artinya sebagain besar masyarakat memiliki pemahaman cukup baik tentang mitigasi bencana untuk pencegahan risiko pandemi Covid-19. Dimana tingkat pemahaman tersebut bisa dilihat dari tiga aspek, yaitu: 1) pengetahuan, 2) sikap, dan 3) tindakan.

Pertama, tingkat pemahaman masyarakat dilihat dari aspek pengetahuan termasuk dalam kategori cukup. Artinya, sebagian besar pengetahuan masyarakat yang menjadi responden tentang 


\section{WAHANA DEDIKASI}

pencegahan covid-19 sudah menunjukkan kriteria baik. Meskipun masih ditemukan beberapa masyarakat dengan pengetahuan tentang covid-19 yang masih kurang. Kurangnya pengetahuan masyarakat dikarenakan oleh masih rendahnya tingkat pendidikan masyarakat Kecamatan Dau kususnya Desa Kucur. (Budiman dan Agus Rianto, 2013) menyatakan bahwa tingkat pendidikan seseorang yang tinggi akan mempermudah dalam menerima informasi, sehingga akan semakin banyak pengetahuan yang diperoleh.

Kedua, pemahaman masyarakat dilihat dari aspek sikap termasuk dalam kategori baik. Sikap adalah salah satu unsur kepribadian yang harus dimiliki seseorang untuk menentukan tindakannya dan bertingkah laku terhadap suatu objek disertai dengan perasaan positif atau negatif (Azwar, 2013). Sikap baik masyarakat terlihat dari sebagian besar masyarakat sudah menerapkan protokol kesehatan sesuai anjuran pemerintah $(5 \mathrm{M})$. Hal tersebut terlihat pada setiap rumah penduduk disediakan tempat cuci tangan yang merupakan salah satu sikap dalam penerapan protokol kesehatan.

Ketiga, tingkat pemahaman masyarakat dilihat dari aspek tindakan termasuk dalam kategori cukup. Perilaku masyarakat dalam bertindak khususnya masyarakat Desa Kucur Kecamatan Dau sangatlah penting guna membantu masyarakat itu sendiri dalam mengatasi pandemic Covid-19. Perilaku masyarakat yang belum bisa maksimal dilaksanakan dalam kehidupan sehari-hari terlihat dari masyarakat yang kurang peduli dengan penggunaan masker. Meskipun masyarakat sudah mengetahui bahwa pemerintah mewajibkan menggunakan masker karena merupakan salah satu langkah pencegahan penyebaran virus, tetapi masih

ada beberapa masyarakat yang mengabaikan. Perilaku tersebut harus didasarkan atas kesadaran masyakat, karena banyak masyarakat yang sebenarnya telah mengetahui berbagai pengetahuan terkait protokol kesehatan dan pandemi Covid-19 namun tidak dapat melaksanakannya secara baik didalam kehidupannya sehari-hari (Tentama, 2018). Akan tetapi ada beberapa masyarakat yang sudah menunjukkan tindakan peduli dengan pencegahan penyebaran virus covid-19 dengan mengikuti kegiatan penyuluhan yang dilakukan oleh pemerintah melalui kepada desa dan organisasi karang taruna desa guna mencegah Covid-19.

\section{KESIMPULAN}

Berdasarkan hasil pelaksanaan kegiatan pengabdian Pencegahan Risiko Pandemi Covid-19 melalui Pendidikan Mitigasi Bencana pada Masyarakat Kecamatan Dau Kabupaten Malang, dapat disimpulkan bahwa pemahaman masyarakat berdasarkan hasil angket Pencegahan Risiko Pandemi Covid19 melalui Pendidikan Mitigasi Bencana yang diisi oleh responden dilihat dari aspek pengetahuan, sikap, dan tindakan dikategorikan memiliki tingkatpemahaman yang sedang.Pembacaselanjutnyadiharapka nmembekalidiridenganpengetahuanpr aktistentangpencegahan Covid19gunamengurangipenyebaran virus. 


\section{WAHANA DEDIKASI}

DAFTAR PUSTAKA

Abdullah, N. (2018). Masyarakat Harus Mengerti Pentingnya Mitigasi Bencana.

https://kabar24.bisnis.com/read/2 0180305/15/746162/masyarakatharus-mengerti-pentingnyamitigasi-bencana

Azwar, S. (2013). Sikap Manusia Teori dan Pengukurannya. Pustaka Pelajar.

Budiman dan Agus Rianto. (2013). Kapita Selekta Kuesioner Pengetahuan dan Sikap dalam Penelitian Kesehatan. Salemba Medika.

Imansyah, F. dkk. (2021). Mencegah Covid-19 Dengan Pembelajaran Aktifitas Fisik Yang Menarik Bagi Siswa Pada Masa Transisi Tatanan Hidup Baru. Wahana Dedikasi: Jurnal PkM Ilmu Kependidikan, 4 (2), 12-15. https://jurnal.univpgripalembang.ac.id/index.php/dedik asi/article/view/5842/pdf_33

Setiawan. (2020). UPDATE Virus Corona Malang 4 Juni 2020: 178 Pasien Hingga Singosari Mendominasi Klaster Covid-19. Surya Malang.Com. https://suryamalang.tribunnews.c om/2020/06/04/update-viruscorona-malang-4-juni-2020-178pasien-hingga-singosarimendominasi-klaster-covid-19 Tentama, F. (2018). Penerapan Perilaku Hidup Bersih Dan Sehat (Phbs) Demi Kesejahteraan Masyarakat Kecamatan Tuntang Kabupaten Semarang Jawa Tengah. Jurnal Pemberdayaan: Publikasi Hasil Pengabdian Kepada Masyarakat, 1(1), 13, 1(1), 13 . https://doi.org/10.12928/jp.v1i1. 309 